\title{
A ESCRITA DE SI NA LITERATURA JAPONESA: UMA BREVE ANÁLISE DO DIÁRIO DE TOSA E DO DIÁRIO DA EFEMERIDADE ${ }^{1}$ \\ THE SELF - WRITING IN THE JAPANESE LITERATURE: $A$ BRIEF ANALYSIS OF THE TOSA DIARY AND THE GOSSAMER YEARS
}

\author{
Joy Nascimento Afonso ${ }^{2}$ \\ Gabriela Kvacek Betella ${ }^{3}$
}

Resumo: Embora na atualidade a literatura oriental possa ser percebida com mais facilidade em nosso cotidiano, devido à globalização do mercado editorial e à possibilidade de acesso às traduções para a língua portuguesa, parece-nos que pouco se conhece de obras canônicas da cultura japonesa. Muito do que temos acesso hoje - obras representativas da literatura contemporânea - foi influenciado pela literatura clássica, por mais que possa parecer contraditório em termos de inovações da prosa. O presente artigo tem como objetivo analisar, de forma breve, duas obras clássicas da literatura japonesa sob o enfoque da voz narrativa diaristica, atualmente conhecida como produção intimista ou escrita de si. Apesar de constituírem de fato dois diários, as vozes narrativas das duas obras possuem características peculiares, refletem a sociedade e a cultura da época de maneira particular. Dessa forma, temos acesso, também, ao período de florescimento da cultura autóctone japonesa, onde escrita e literatura se formaram no país. Os dois diários aqui analisados, contemporâneos entre si, influenciaram profundamente a literatura japonesa, visto que foram as primeiras obras escritas utilizando-se da voz narrativa feminina. $\mathrm{O}$ Diário de Tosa, escrito pelo poeta Ki no Tsurayuki (872 - 945), tem como narradora uma dama

1 Artigo submetido em 29/5/2020 e aceito em 26/11/2020.

2 Docente da área de Japonês no Departamento de Letras Modernas na UNESP, Assis-SP/ Brasil. Doutoranda do Programa Literatura e Vida Social UNESP-Assis e mestre em Língua, Literatura e Cultura Japonesa pelo Departamento de Letras Orientais da FFLCH-USP, com ênfase em literatura moderna japonesa; joy.afonso@unesp.br (ORCID iD: http://orcid.org/0000-0002-0994-5524).

3 Docente da área de Italiano no Departamento de Letras Modernas na UNESP, Assis - SP/ Brasil. Doutora e mestre em Teoria Literária e Literatura Comparada pela FFLCH-USP, pós-doc no IEB-USP, com trabalhos de análise de narrativas em primeira pessoa e gêneros híbridos autobiográficos: diários, cartas, autobiografia, crônica; kvacek.betella@unesp.br (ORCID iD: http://orcid.org/0000-0003-2977-132X) 
que acompanha a viagem de retorno do governador de Tosa e seu séquito à capital Heian, e no Diário da Efemeridade, a autora conhecida apenas como Mãe de Michitsuna (936 - 995) assume a voz narrativa, a fim de relatar suas próprias memórias como dama da corte, casada com um dos príncipes regentes da Corte de Heian.

Palavras-chave: Diários; Literatura Japonesa; Diário de Tosa; Diário da Efemeridade.

Abstract: Although nowadays oriental literature can be more easily perceived in our daily lives, due to the globalization of the publishing market and the possibility of access to translations into Portuguese, it seems to us that little is known about the canonical works of Japanese culture, although much of what we have access to today - contemporary literature was influenced by this classical literature. This article aims to briefly analyze two classical works of Japanese literature under the focus of the daily narrative voice, currently known as intimate production or writing of itself, where despite being two diaries, their narrators have peculiar characteristics, reflecting the society and culture of the time in a particular way. In this way we also have access to the period of flowering of the native Japanese culture, where writing and literature were formed in the country. The two diaries analyzed here, contemporary at the time of their production, deeply influenced Japanese literature, since they were the first works written using the female narrative voice. The "The Tosa Diary", written by the poet Ki no Tsurayuki (872 - 945), has as its narrative voice a lady who accompanies the return trip to the capital journey of the governor of Tosa and his entourage to the capital Heian, and in the "The Gossamer Years", the author known only as the Mother of Michitsuna (936 - 995) assumes the narrative voice in order to relate her own memories as a lady of the court, married to one of the princes regents of the Court of Heian.

Keywords: Diary; Japanese Literature; The Tosa Diary; The Gossamer Years.

\section{INTRODUÇÃO}

Sempre que indagamos aos nossos alunos ingressantes na graduação, cuja habilitação será língua japonesa, sobre o que eles conhecem ou já ouviram falar de literatura japonesa, a resposta mais comum são os mangás, as revistas em quadrinhos, que reforçam a cultura pop japonesa entre os jovens brasileiros. Entretanto, o que poucos sabem é que muito da cultura popular produzida na atualidade tem suas bases nas artes clássicas japonesas e isso também inclui a literatura. Algumas delas, inclusive, produzidas por mulheres. Dessa maneira, como estudiosos de literatura, faz-se necessário olharmos para as origens da literatura japonesa, a fim de depreendermos o fio que conecta temas e escritas. Nossa proposta aqui é revelar como a escrita feminina (definida pelo ponto de vista feminino) na modalidade diaristica, tornando-se um gênero literário - o nikki bungaku (literalmente literatura de diários), traçando uma espécie de espinha dorsal da narrativa intimista, a ponto de ser possível identificar aspectos do modo de lidar com os sentimentos na literatura japonesa contemporânea e em outras manifestações culturais.

Esse período de florescimento cultural no qual as artes, hoje reconhecidamente japonesas, iriam surgir como representação de uma sociedade que valorizava acima 
de tudo a beleza estética, foi marcada também pela criação dos gêneros literários, tais como: Monogatari - Prosa Ficcional, Shû - "Coletânea de poemas sazonais", Zuihitsu "Ensaios filosóficos" e Nikki Bungaku, conhecido como a "Literatura de Diários". Este último mesclava em seu texto prosa, poesia, cartas e reflexões filosóficas.

Tal desenvolvimento literário também se tornou a base da escrita japonesa, visto que, enquanto nos templos budistas os monges, a fim de conseguir transmitir os ensinamentos religiosos aos nobres, desenvolveram a escrita conhecida como katakana, concomitantemente, na Corte do período Heian (794 - 1192), as damas da corte desenvolviam a escrita cursiva, ou hiragana, que na atualidade é utilizada para grafar palavras de origem japonesa e sufixos morfológicos. Naquele período, a escrita feminina, ou onnade, representou a resistência de um sentimento claramente nipônico: o desejo de dizer o que se sentia, seja na prosa ou na poesia, diante das mudanças dos tempos. Nas palavras de Suzuki (1992), que nos explica de forma mais clara essa mudança na escrita e na literatura, é:

Das mãos das mulheres que nascem o kana e boa parte da literatura da época, principalmente diários e contos. Kana é o estilo de grafia originado de um estilo de caligrafia cursivo do ideograma, empregado em seu uso fonético, que permitiu aos japoneses se expressarem na própria língua, dando vazão a seus sentimentos com maior liberdade do que quando faziam em chinês, como até então. Os letrados eram levados a pensar em japonês, reproduzindo em texto chinês seu pensamento, para depois retraduzir em japonês no ato da leitura. Com o kana, o fluir das idéias corre mais solto e nasce uma vasta literatura, agora de expressão japonesa por excelência, principalmente pelas mãos das mulheres. O estilo chinês acaba sendo característico dos documentos oficiais, embora tenha se mantido a tradição da poesia chinesa, muito estimada pela elite palaciana. (SUZUKI, 1992, p. 141)

Portanto, ao desenvolver uma grafia capaz de expressar melhor os sentimentos, diretamente na língua natal, o estilo "feminino" incorpora o relato da intimidade de modo a adequar forma e conteúdo numa expressão mais detalhada, configurando apenas uma das particularidades dos diários japoneses, em relação à "escrita de si" ocidental, que nos fazem relativizar alguns conceitos da fortuna crítica angariada por essas formas narrativas.

Em comparação aos diários ocidentais, que oferecem ao leitor uma visão histórico-social do autor, muitas vezes um grande escritor, pensador ou indivíduo ligado à vida cultural ou política, os diários japoneses, segundo Earl Miner (1968), salientam mais especificamente as recordações privadas do autor, mais do que seus relatos em contextos públicos. Dessa forma, o diário literário japonês "enfatiza o amor mais do que o casamento, a morte mais do que as batalhas mortais, a família mais do que a vida pública" (p.38). Isso porque, segundo Miner (1968), o diarista japonês consegue articular, por meio de suas experiências pessoais, o sentimento humano que perpassa os anos. Buscando em "eventos privados um significado universal ou uma temática crescente acima da mera sequência das atividades diárias" (MINER, 1968, p.39). 
O que depreendemos dessa afirmação é que, embora a produção intimista ocidental valorize apenas a descrição do dia a dia do autor, levando o leitor a refletir sobre sua própria vida, a produção diaristica japonesa, ao descrever seu cotidiano, preza pela visão universal ali inserida em sua vivência. Assim, embora as experiências do narrador nipônico não pareçam profundas em uma primeira leitura, perceberemos que existe uma escolha única, pois visa aquilo que é universal. Vamos explorar como essa relação entre o particular e o universal pode ser mais complexa, tratando-se dos diários japoneses de Heian.

Miner (1968) divide os diários em dois grupos: diários "naturais" ou comuns e diários artísticos. Os diários japoneses normalmente entrariam no segundo caso, por mesclarem na sua prosa poesia, epistolografia e ficção. Para o estudioso, enquanto o diário natural, ou comum, enfoca os fatos cotidianos da experiência vivida, os diários nipônicos destacam "o fluxo do tempo, e não a concatenação dos eventos, que é importante, e é o repentino brilho da experiência poética, e não a ordem de uma cidade bem iluminada, que dá aos diários seu senso de profundidade da experiência" (MINER, 1968, p.46). Dessa forma, os diários que aqui serão analisados terão uma perspectiva mais artística do que apenas cotidiana.

Para essa análise, escolhemos dois dos mais conhecidos diários da literatura clássica japonesa: o Diário de Tosa (Tosa Nikki) e o Diário da Efemeridade (Kagerô Nikki). O primeiro escrito em 935, pelo renomado poeta da Corte, Ki no Tsurayuki (870-975), no qual relata a viagem do governador de Tosa, atual província de Kôchi, até a capital Kyoto. O segundo diário foi composto pela mulher conhecida apenas como Mãe de Fujiwara no Michitsuna (936 ?- 995) e traz o relato de 21 anos da vida da autora.

\section{O DIÁRIO DE TOSA - A VOZ NARRATIVA FEMININA}

O Diário de Tosa (Tosa Nikki) é tido como o primeiro texto diaristico da literatura japonesa. Ki no Tsurayuki se utiliza da voz narrativa feminina. Apesar disso, para Miner (1968), a obra não deixa de ser apenas um diário "comum" ou natural, pois embora crie um narrador ficcional, a descrição dos fatos e das experiências das personagens continua prezando o modelo chinês com entradas de datas, como um relatório de viagens elaborado para o imperador, sem a demonstração de emoções pela narradora.

Segundo Nagae, o Diário de Tosa resume-se no seguinte,

Em 930, Tsurayuki foi designado governador da Província de Tosa, atual Província de Kôchi, localizada na ilha de Shikoku ao sudoeste do arquipélago japonês, para um mandato de quatro anos que se estendeu por mais um ano, devido ao atraso da chegada de seu sucessor, e o Diário de Tosa narra a viagem de volta de Tsurayuki e sua comitiva para a Capital, na forma de um diário que tem início no dia 21 de dezembro de 934, data em que ele deixa o palácio do governo após a recepção do novo governador e a troca de posse, e termina com chegada em sua residência em 16 de fevereiro de 935, cinquenta e cinco dias depois. (NAGAE, 2007, p.151) 
O relato de Ki no Tsurayuki se inicia de forma pouco ortodoxa para a época, pois tendo em vista que o autor tinha uma posição de destaque na sociedade de Heian, dizer o que sentia, por meio da escrita em prosa, não era algo comum aos homens. Assim como para o governador, autor desse diário, era comum o relato de viagem, escrito em chinês, a fim de relatar ao Imperador o dia a dia da província e dos tratados políticos. Vejamos o trecho inicial a fim de verificar a forma encontrada pelo autor, para descrever o seu dia a dia:

Em geral, é um homem que escreve um diário oficial registrando-o em chinês, mas como mulher, farei um diário na escrita feminina japonesa.

Por volta das oito horas da noite do vigésimo primeiro dia do décimo segundo mês de determinado ano, um homem partiu em viagem. A esse respeito relatá-lo-ei neste modesto registro.

Certa pessoa cumpriu há pouco seu mandato de quatro ou cinco anos. Concluiu todos os seus trabalhos de incumbência de seu governo e entregou a documentação necessária ao seu sucessor. Deixou a residência oficial do governador e dirigiu-se ao local de embarque. Amigos e desconhecidos vieram despedir-se. Pessoas que lhe serviram fielmente durante vários anos começaram a sentir a tristeza da separação. Durante o dia todo, houve muita euforia até que a noite chegou. (KI NO TSURAYUKI, 2014, p.1, trad. Neide Nagae, grifo nosso).

Nesse longo trecho introdutório, é possível notar claramente dois fatos: 1) há uma justificativa para que a voz narrativa seja feminina, e para isso, 2) o autor cria uma terceira persona - "um homem", sobre quem "a mulher" irá falar. Embora essa técnica de criar uma terceira personagem, a fim de falar de si mesmo com certa distância, aconteça com certa frequência na literatura contemporânea, a obra aqui exposta é do século X, o que revela uma visão autêntica do autor japonês.

Essa técnica, de criar uma segunda e até terceira pessoa, para se detalhar uma autobiografia, seria o que Philipe Lejeune define como "o pacto implícito ou explícito que o autor estabelece com o leitor, através de vários indicadores presentes na publicação do texto" (LEJEUNE, 1996 apud KLINGER, 2007, p.12). Embora a técnica discutida pelo autor francês seja algo moderno, pode ser aplicado ao diário aqui apresentado, se olharmos para a obra em sua estrutura formal, em que pode se notar claramente três "vozes" narrativas distintas: o autor por si mesmo, por vezes transparecendo na forma como o relato é construído, enquanto autor onisciente intruso, "a mulher" como narrador onisciente neutro, em que relata o que vê durante a viagem, e "o homem", que narra principalmente na última parte do diário, mudando de turno com "a mulher" e assumindo a narração neutra, que seria o autor por ele mesmo. Isso significa que, a fim de se resguardar ou assegurar a distância de sua narrativa, o autor opta por três vozes narrativas distintas, possivelmente criando um ambiente de verossimilhança para seu leitor, visto 
que os sentimentos do autor estariam evidentes na narrativa. Para essa categorização da voz narrativa, seguimos as premissas propostas por Norman Friedman (2002).

Segundo a categorização de Friedman (2002), o "autor onisciente intruso" está longe da cena, "pois é a voz do autor que domina o material, falando frequentemente por meio de um 'eu' ou de um 'nós"” (FRIEDMAN, 2002, p.173). No caso do Diário de Tosa, essa voz só é percebida devido, como podemos notar no trecho supracitado, a uma escrita formal utilizada apenas por homens que possuíam cargos, como o de governador de uma província. O detalhamento das horas de partida, dos atos cerimoniais e das atitudes "do homem" narrado destacam a escrita utilizada nos relatórios enviados para a corte, mais do que de um relato pessoal, como num diário íntimo. A fim de ressaltar essa categoria, ressaltamos o trecho a seguir:

Vigésimo sexto dia. Ainda na casa do governador, houve uma recepção pomposa e até os servos foram presenteados. Poemas chineses foram recitados. Poemas japoneses foram recitados pelo anfitrião, pelos visitantes e pelos desconhecidos. Os poemas chineses não os registrei aqui. Eis o poema japonês que o novo governador compôs:

Sai da Capital pensando em vir para te encontrar/vim á toa, logo iremos nos separar, (KI NO TSURAYUKI, 2014, p.2, trad. Neide Nagae, grifo nosso).

A voz do autor, mais do que da "mulher" narradora, é clara quando a escolha do poema selecionado para ser citado na obra foi feito em homenagem ao "homem" que se despede da província, escrito e declamado pelo novo governador.

A voz narrativa feminina, neste caso, pode ser categorizada como "narrador onisciente neutro", podendo ser o espectro do próprio autor, que embora não se exima de se utilizar da $1^{\text {a }}$ pessoa - "eu" para narrar, a fim de poder falar de sentimentos que não caberiam em um relatório de viagem, utiliza-se dessa voz para ressaltar as saudades que sentia da filha, que havia falecido durante sua estadia na província de Tosa.

Vigésimo sétimo dia. Partimos de Ôtsu, na cidade de Kôchi rumo a Urado, cerca de 12 quilômetros a noroeste dali.

\begin{abstract}
A filha do ex-governador, que nascera na Capital quando ele ainda tinha posição, havia falecido na Província de Tosa de modo súbito e, agora, diante dos preparativos para a partida, com vistas a retornar a Kyoto, ele emudece diante da tristeza e da saudade da filha perdida. As pessoas ali presentes também não se continham de tanta tristeza. Nesse ínterim, alguém escreveu e apresentou o seguinte poema:
\end{abstract}

A tristeza de quem retorna a Capital é por quem não retornará 
E assim recitou outra vez:

Esqueço da morte da criança. Por vezes pergunto por ela. Que tristeza! (KI NO

TSURAYUKI, 2014, p.7, trad. Neide Nagae, grifo nosso).

Nesse excerto fica nítido o porquê da escolha da voz narrativa feminina para a narração deste diário. Na corte de Heian, a escrita feminina desenvolvia-se pelo viés ficcional e intimista. Conhecendo este tipo de produção, o autor se utiliza daquilo que acreditava ser "feminino", como a atitude de deixar transparecer na escrita as saudades que sentia da filha, porém mantendo no texto a descrição feita por "uma mulher". Esta, com sua sensibilidade, conseguiria transcrever o que provavelmente um burocrata não se preocuparia em inserir no relato de viagem.

Outro aspecto interessante desta técnica utilizada pelo autor é que, sendo a narradora uma mulher, o relato, os sentimentos de medo pela viagem e tristeza pelas lembranças são ressaltados como se a narradora não estivesse vivenciando, mas sim apenas assistindo à viagem da comitiva.

Trigésimo dia. Não há chuva e nem vento. Ouvimos que "os piratas não atacam à noite". No meio da noite, portanto, desatracamos o barco e atravessamos o estreito de Awa. Na escuridão, não distinguíamos o oeste do leste. Os homens e as mulheres rezavam orações xintoístas e budistas com fervor até que finalizamos a travessia. (KI NO TSURAYUKI, 2014, trad. Neide Nagae, p.14)

Nesse trecho podemos observar como essa narradora se coloca frente à experiência de viagem, o que possivelmente deve causar ao leitor uma sensação de superficialidade, conforme se observa no fragmento mencionado os viajantes passavam por intempéries e medos de assaltos, mas a narradora não parece se afligir, e apenas descreve a sensação do resto da comitiva. Em nenhum momento do diário a narradora revela o que sente, seu relato é baseado no que ela vê. Nesse aspecto, a estrutura desse diário se afasta da dos demais, ao ter como foco a descrição do sentimento do governador, do homem, e não de si mesma, como narradora e "autora" da obra.

Por último, "o homem" escolhido para ter sua viagem narrada, conforme vimos no primeiro excerto - "Certa pessoa cumpriu há pouco seu mandato de quatro ou cinco anos. Concluiu todos os seus trabalhos de incumbência de seu governo e entregou a documentação necessária ao seu sucessor" (KI NO TSURAYUKI, 2014, p.1), seria, a nosso ver, a terceira voz do autor da obra. Sob esse aspecto é importante notarmos que, embora o diário tenha por objeto a figura desse homem, sua voz não aparece na maior parte do texto, surgindo apenas nas transcrições de suas poesias, no início do diário e, repentinamente, assumindo a voz narrativa, na última parte do diário, conforme constatamos a seguir: 
Como grande parte da propriedade estava devastada, as pessoas diziam: "Que lástima!". Tudo trazia recordações, e, dentre tudo, a menina que nasceu nesta casa não ter retornado é de imensa tristeza. As pessoas do barco e as crianças, todos, estão em grande euforia. Nisso, sem suportar tamanha tristeza, recitou um poema às ocultas, com alguém mais próximo:

Que tristeza ver o pequeno pinheiro que nasceu em nossa casa, quando até a criança que nasceu nesta casa não voltou.

Sendo ainda insuficiente, recitou:

Se aquela menina vivesse mil anos como o pinheiro que vejo, não teria feito a triste e eterna despedida.

Há muitas coisas inesquecíveis e memoráveis para se relatar, mas são difíceis de fazer. Seja como for, vou rasgar logo... (KI NO TSURAYUKI, 2014, p.21, trad. Neide Nagae, grifo nosso).

$\mathrm{Na}$ última parte do texto ocorre uma troca de vozes narrativas. $\mathrm{O}$ autor decide assumir seu próprio relato. Por ser, o que Miner (1968) chamou de "Diário Ficcional", tendo como voz narrativa principal uma mulher, podemos categorizar essa última voz narrativa, como "narrador onisciente neutro", de modo que houvesse apenas uma mudança de turno narrativo.

No excerto supracitado, "o homem", ao retornar a sua antiga casa na capital, se depara com total abandono e memórias de tempos idos. Espontaneamente, assume também a voz narrativa e fala em secreto possivelmente com sua esposa - "recitou um poema às ocultas, com alguém mais próximo" (KI NO TSURAYUKI, 2014, p.21), sobre as saudades que sentia ao recordar o nascimento da filha naquela casa. Talvez possamos afirmar que, apesar da insistência em se manter distante do seu relato, diante da tristeza que só alguém próximo partilharia, o autor se revela sem nenhum constrangimento. $\mathrm{Ou}$ ainda, estaria se mostrando de modo pleno porque, possivelmente, sua viagem chegava ao fim e ele não teria mais que dar explicações oficiais como governador.

Embora, nesse momento, o autor assuma a voz principal em primeira pessoa, ele prefere se omitir, a fim de não se expor diante de seus servos, que, diferentemente dele, regressavam felizes à capital. Nesse momento em que a sua real tristeza vem à tona, inclusive em sua escrita, o autor interrompe o relato a fim de preservar a sua imagem: "Há muitas coisas inesquecíveis e memoráveis para se relatar, mas são difíceis de fazer. Seja como for, vou rasgar logo...” (KI NO TSURAYUKI, 2014, p.21, grifo nosso). É necessário ressaltar ainda, ao encerrar este parágrafo, o seguinte: a partir da leitura do Diário de Tosa, podemos observar, de forma clara, as três vozes narrativas que colaboram com a estruturação da obra, pois escondem a imagem do autor real, embora o encontremos através do discurso formal, que destoa de uma obra memorialística, ao compararmos com o diário da Mãe de Michitsuna. Permitindo, assim, que o leitor observe por meio dos fragmentos poéticos mencionados os sentimentos suprimidos pelo autor, 
a fim de preservar o status de seu cargo. Percebemos aqui movimentos narrativos em combinação inovadora: em primeiro lugar, temos a criação de uma estrutura narrativa complexa para uma obra de finalidade relativamente simples, o que nos leva a indagar acerca da elaboração de eventos privados com ênfase na particularização, que fica em evidência por meio do relatório de viagem e dos poemas, como se a representação não fosse suficiente com apenas uma das modalidades. Em segundo lugar, em meio aos desdobramentos do "eu", temos a revelação de sentimentos pelo eu-lírico dos poemas (portanto, o desvelamento do sujeito) e, em contrapartida, a ocultação parcial da identidade de quem confessa. Se o autor desejava se esconder por trás de uma manipulação de ponto de vista, na tentativa de oferecer aos fatos particulares um significado universal, sua estratégia fundadora capta e sintetiza um comportamento social.

\section{O DIÁRIO DA EFEMERIDADE - VOZ E AUTORIA FEMININA}

durante o período Heian (794 - 1192), devido a uma necessidade social, as mulheres que serviam na corte eram letradas e versadas na escrita e na poesia chinesa. Essa necessidade se dava em virtude dos contratos políticos que as famílias da nobreza constituíam com a família imperial. Dessa forma, era comum que essas mulheres fossem conhecidas, além da preocupação com a beleza física, também pela sua escrita - "shodô" (arte da caligrafia), pela sua produção poética e ficcional, e por terem conhecimento dos cerimoniais da corte.

Nas palavras de Suzuki (1992), mais do que um bom casamento, servir à família imperial também proporcionava certo status para a família da moça, que por vezes era usada como moeda de troca em conchavos políticos.

Os nobres que enviavam as filhas como nyôgo ou shôji ao palácio faziam-nas acompanhar mulheres cultas, isto é, que dominavam artes como a da composição poética, da música, da caligrafia, da dança, muito requisitadas nas festas palacianas, sendo, inclusive, quesitos de promoção quando executadas com qualidade a ponto de chamar a atenção dos presentes. Ser escolhida como dama de companhia era, portanto, muito disputado entre as famílias de média e baixa hierarquia ou por clãs, como o Fujiwara, que usaram as filhas como um meio de promoção ou de ascensão ao poder (SUZUKI, 1992, p.141).

Assim, o ideal estético e intelectual cobrado das mulheres dependeria dos cargos ou do casamento que a família planejaria para a dama. É nesse contexto que o Diário da Efemeridade foi escrito.

O que sabemos da autora dessa obra, além daquilo que está no diário, é que ela era a mãe de um grande general do período Heian - Fujiwara no Michitsuna, e esposa de um dos príncipes da época - Fujiwara no Kaneie (929- 990). Naquele período, as mulheres eram reconhecidas por seus cargos, ou pelos títulos de seus consortes. No caso da autora não foi diferente, ela fica conhecida pela ligação sanguínea que teve com o general, sendo 
assim não temos acesso ao verdadeiro nome da escritora. A obra, segundo Seidensticker (1994), tradutor do diário para a língua inglesa, é "uma autobiografia - um diário que cobre 21 anos da vida de uma nobre dama do médio Heian, conhecida hoje como "a mãe de Michitsuna"' (SEIDENSTICKER, 1994, p.6). Nos manuais de literatura clássica, a autora é lembrada "por seu casamento infeliz com Fujiwara no Kaneie, iniciado em 954 com as primeiras cartas de amor dele, e finalizado em 974, com seu distanciamento quase completo" (SEIDENSTICKER, 1994, p. 7).

A obra é dividida em três volumes, e subdividida em anos, não seguindo uma ordem cronológica. A voz narrativa em primeira pessoa, além de ressaltar as rememorações da Mãe de Michitsuna, também revelam a coragem assumida pela autora em falar de forma aberta, quase como um manifesto crítico à situação das mulheres quem viviam na corte de Heian. A narrativa tem início em 954 quando Kaneie, representante de uma das famílias mais poderosas de Heian, corteja a autora, que na época era uma reconhecida poetisa. O casamento, estratégia política comum entre as famílias, reforçaria o poder político do clã do qual fazia parte a autora e daria status a Kaneie, que, ao casar-se com uma poetisa, seria visto com um nobre que preservava valores culturais.

Diferentemente da primeira obra, anteriormente apresentado nessa análise, a obra da Mãe de Michitsuna segue uma estrutura mais próxima a um diário de recordações, ou uma autobiografia, com entradas em anos e datas específicas. O tom é mais intimista, apesar de nos dois primeiros livros a autora utilizar-se da voz em terceira pessoa, nomeando-se como "a dama", talvez a fim de observar a si mesma em outra época, permitindo-se criar uma terceira personagem de si mesma. Segundo Mathias, que discute a forma dos diários memorialísticos, "toda tentativa autobiográfica [...] é a de conferir forma e sentido a algo inacabado: a própria vida de quem escreve" (MATHIAS, 1997, p.42). Sendo assim, mais do que narrar o seu cotidiano, a dama da corte de Heian busca entender a própria vida, por si mesma.

Assim, ao lermos e nos debruçarmos sobre essa obra, damos voz a alguém que nem mesmo o nome real se conhece, mas que por meio de sua escrita, tornou-se visível ainda hoje. Ainda citando Mathias (1997), "o diário possui, de fato, a particularidade única que não existe em nenhum outro texto literário de poder ser interrompido pela morte sem que por isso fique inacabado" (MATHIAS, 1997, p. 47). Portanto as memórias da Mãe de Michitsuna permanecem vivas e revisitadas quando lidas.

O Livro I inicia-se com a autora reconhecida por seu talento - ela nega tal fato na introdução do diário, mas há inscrições históricas que atestam isso - e que passa a ser cortejada pelo príncipe, que já possuía uma esposa. Naquela época, a poligamia era permitida para os homens. Embora a poetisa houvesse dado várias respostas negativas às investidas do príncipe, ele insiste e, um ano depois, a relação do casal é oficializada perante a corte, quando ele a leva para viver em uma casa somente para o casal.

A abertura da obra, passados anos, após o primeiro encontro do casal e do casamento, é o mote para a construção do diário. Uma espécie de caminho às avessas pela memória da autora, que busca entender seus relacionamentos. 


\section{Livro I}

Nestes tempos que passaram, e era ela quem certamente havia se afastado deles, mal sabendo onde ela estava. Talvez fosse natural que isso seria a sua sina. Ela era a menos bonita do que a maioria das mulheres, e não era extraordinariamente talentosa. No entanto, à medida que os dias passavam monotonamente, ela teve a oportunidade de olhar para os romances antigos e encontrou neles massas da mais grosseira invenção. Talvez, ela tenha dito a si mesma, que talvez até a história triste da sua própria vida, colocado em um diário poderia ter algum interesse; e isso poderá responder a uma pergunta: Que tipo de vida seria condizente com uma dama bem nascida? No entanto, eles têm a necessidade de serem relatados, os eventos de muito tempo atrás, e os eventos de ontem. E ela não tem certeza de como colocá-los em ordem. (MICHITSUNA NO HAHA, 1994, trad. nossa, p.33)

No excerto de abertura, fica clara a intenção da autora que após longos anos se dá conta da efemeridade da vida, em especial da vida da mulher, que vivia em função do marido. Olhar para os amores e para as histórias passadas lhe ajudaria a entender o presente e colocar em ordem as suas próprias memórias.

A primeira parte da obra é a rememoração da época em que a autora conhece o ainda príncipe Kaneie. Ela era jovem e cobiçada por vários jovens, mas não tinha a pretensão de se casar. Não à toa, apesar das investidas por cartas e poemas, ela não cedia à sedução do rapaz, conforme trecho a seguir:

Eu não deveria mostrar as notas frívolas de amor que tenho recebido de tempos em tempos. Ultimamente o príncipe tem começado a me enviar mensagens. A maioria dos homens teria passado por um intermediário adequado, uma senhora que ficaria esperando, talvez, mas ele foi direto ao meu pai dando sinais, possivelmente meio brincando no início, de que ele gostaria de se casar comigo.

Eu estava meio inclinada a não responder, mas minha mãe insistiu em dizer que a carta de um cavalheiro não poderia ser ignorada, e então, finalmente eu enviei a ele um poema: "Não deixe nenhum pássaro desperdiçar seu canto em uma região selvagem, onde ele não encontrará resposta".

Isso foi no começo. Vieram outros poemas, mas eu os deixava sem resposta (MICHITSUNA NO HAHA, 1994, trad. nossa, p.33).

A autora, assim como algumas mulheres de sua época, teve uma boa formação em poesia chinesa, assim como em poesia clássica japonesa. Sendo assim, se utiliza da forma de corte entre os casais da época - cartas com poemas, para responder a sedução de Kaneie. É interessante notar que, mesmo após anos passados dessa experiência, a autora relembra o quanto era desejada, a ponto de fazer o príncipe atravessar as normas sociais - "a maioria dos homens teria passado por um intermediário adequado, 
uma senhora que ficaria esperando, talvez, mas ele foi direto ao meu pai dando sinais" (MICHITSUNA NO HAHA, 1994, p.33), para conquistar a mulher amada. Desse trecho, podemos depreender, que mais do que amor, possivelmente o príncipe desejava ter a dama como um prêmio a ser alcançado.

Como o "amor" do príncipe não poderia ficar sem resposta, a mãe da dama insiste que ela responda. Sua resposta reflete não apenas a sua jovialidade, mas também certo despeito, por entender a real intenção do príncipe: tê-la. A poesia escrita pela dama foi uma resposta à outra carta, que Kaneie teria enviado falando de um pássaro que desejaria cantar em uma região virgem.

Apesar da resposta da dama, o príncipe continua insistindo por meio de cartas e poemas, que são trocados por todo o outono, o que demonstraria uma relação séria entre os dois. No final desse período, o príncipe a leva para morar com ele, em uma residência preparada para o casal. Junto com seus servos, ela parte para uma nova vida. Embora ainda jovem - alguns historiadores dizem que a autora teria entre 15 e 16 anos, na época que casou com Kaneie, ela sonha viver uma vida plena ao lado de um homem, que insistira por meses para estar com ela.

Já nos primeiros anos de casada, nasce Michitsuna - único filho do casal, e apesar da alegria de ser mãe de um menino, que seria herdeiro do cargo do pai, a autora rememora desse período não o nascimento do filho, mas sim a angústia em saber que o marido a estava traindo e a cada dia se afastando mais do lar.

\section{Nono ano de Tenryaku (955)}

Cedo, na manhã de Ano Novo, eu saí para uma curta caminhada. Eu não o via havia dois ou três dias, e então deixei esse poema para ser entregue, se ele me chamasse: "Indesejada, eu saí para chorar no pântano com o tordo".

Dentro em pouco, ele respondeu: "Sua chamada me convocaria, apesar da frivolidade de explicar isso ao vagar pelas florestas com o tordo".

Entretanto, ficou claro que eu deveria ter um filho. Eu passei um dos mais desagradáveis primavera e verão, e no final do oitavo mês, dei à luz um menino. $\mathrm{O}$ Príncipe mostrou todos os sinais de afeição.

No entanto, no mês seguinte, eu recebi uma notícia chocante. Mexendo na minha caixa de escritos, uma manhã logo depois que ele partiu, encontrei um bilhete obviamente destinado a outra mulher. Meu desgosto era infinito, e eu senti que devia pelo menos deixá-lo saber que eu tinha visto algo. "Isso seria uma declaração de separação", escrevi, "esse bilhete que eu vi para outra?" (MICHITSUNA NO HAHA, 1994, trad. nossa, p.37). 
É interessante notar que a escrita da dama é utilizada como a única forma possível de lamento, devido a sua posição social. Ao perceber o distanciamento do marido, a dama sente-se na obrigação de lhe dar um herdeiro. Apesar do esforço em manter o casamento, logo após o nascimento do filho, ela descobre que o marido mantinha uma relação com outra mulher, que se tornaria a sua terceira esposa. Dessa maneira, mais do que apenas deixar inscrita a sua memória, a autora revela a real vida das damas da corte de Heian.

Para Bundy (1991), a autora busca descobrir através da escrita o entendimento para sua vida, sendo assim, o "texto dela é uma negação do romance e a busca por um modelo de narrativa e do sentido de sua vida como mulher na sociedade de Heian" (p. 80). Assim, enquanto se exaltava no período Heian, os encontros amorosos e cavalheiros, o diário da Mãe de Michitsuna torna-se a visão mais realista da vida das mulheres da época.

No segundo livro, a autora descreve as brigas mantidas com o marido devido a seu gênio intempestivo. Eles já estavam casados há anos, e quando o Príncipe vinha visitá-la, gostava de mostrar seu poderio, exigindo que todos os servos da casa o temessem.

\section{Livro II}

No segundo dia do oitavo mês, tarde da noite, o Príncipe apareceu de repente. Seu comportamento era absurdo. "Tranquem todas as portas", ele exigia. "Amanhã todos estarão de penitência". Eu fiquei furiosa. Meus servos se reuniram e ouviram, e em sua consternação puderam apenas imitar-me, e desejar uns aos outros, que nós ficássemos calmos. Eu fui levada para sentar-me com ele, e sem dúvida eu parecia espiritualizada e tola. O Príncipe e eu conversamos sobre tudo no dia seguinte, mas sua fala foi uma série de variações sobre o mesmo tema: "Eu não mudei. Porque você sempre vê tudo sob um prisma errado?". Eu não pude adentrar em minhas respostas. (MICHITSUNA NO HAHA, 1994, trad. nossa, p. 91)

Nesse excerto, pode-se notar de forma mais clara que, apesar da dificuldade de diálogo que havia entre o casal, a autora segue o cerimonial de não discutir na frente dos servos, e segue os rituais pré-estabelecidos. Apesar disso, ela consegue impor, mais do que nos primeiros anos do casal, a sua visão diante do marido, revelando um amadurecimento de sua própria personalidade. No entanto, ele parece não ouvi-la. Por isso, conforme excerto que segue a dama, nega-se a servi-lo a fim de que ele perceba que a magoa. Para isso, ela utiliza-se de uma estratégia feminina ainda utilizada em nossos dias: nega-se a fazer sexo com ele, fingindo que está dormindo.

Respondi que eu não me sentia bem e poderia não respondê-lo. Eu tinha certeza de que não poderia vê-lo, mas inesperadamente ele apareceu frio e indiferente como sempre. Sua maneira brincalhona me irritou mais ainda, e antes que eu pudesse perceber, comecei a derramar todo o ressentimento guardado por meses. Ele não disse uma palavra, fingindo estar dormindo, e depois de um tempo, ele exclamou: "O que é isso? Você já foi deitar-se?". 
Ele pode não ser inteiramente gracioso comigo, mas eu me tornarei uma pedra pelo resto da noite, e ele se levantou cedo pela manhã sem dizer nenhuma palavra.

(MICHITSUNA NO HAHA, 1994, trad. nossa, p. 95)

É interessante notar, que nessa segunda parte do diário, o texto se torna mais corrido e há poucas interrupções com entradas de datas, possivelmente porque a autora passa a escrever de acordo com as lembranças que lhe vinham à mente. Nesse caso, a lembrança relatada é de uma situação em que, mesmo a dama sendo sincera com o marido, ele continuava impassível diante de seus sentimentos. Uma observação determinante sobre a voz narrativa é que, a partir do segundo livro, a autora adota a voz narrativa em primeira pessoa: "eu", assumindo não apenas suas memórias, mas também a sua voz.

Na última parte do diário, no Livro III, nota-se uma presentificação maior dos acontecimentos, embora a autora se refira a fatos ocorridos durante a infância do filho, fase em que seu marido se afasta ainda mais da família, conforme excerto que segue:

\section{Livro III}

No oitavo mês, houve uma epidemia de varíola. Que se espalhou deste lado da cidade até o centro, em um mês; e meu filho acabou acometido da doença de forma severa. Eu havia praticamente rompido toda a comunicação com o pai dele, mas a situação estava tão séria, que senti que realmente deveria reportar a ele sobre a situação. Estava pensativa comigo mesma, preocupada e triste. Finalmente, eu decidi que não havia como evitar e escrevi uma carta. Ele enviou uma réplica demasiadamente fria, e apenas uma vez na mensagem perguntou como o menino estava, e isso foi tudo. As pessoas que não precisavam me perguntavam sobre o menino, mas ele [o pai] permanecia afastado, e isso aumentava uma nova angústia, além da angústia da doença do menino. Até mesmo o Kami ${ }^{4}$ apareceu sem rodeios agora e antes. No início do nono mês, o menino começou a se recuperar (MICHITSUNA NO HAHA, 1994, p. 162, tradução nossa)

No excerto supracitado, fica clara a base da relação que o Príncipe mantinha com a autora - apenas a obrigação como marido e pai, e mesmo essas "funções" não cumpria com eficácia devido a outro matrimônio que havia contraído. Por isso nos faz retornar ao excerto do início do diário, em que a autora busca entender "os romances antigos e encontrou neles massas da mais grosseira invenção" (MICHITSUNA NO HAHA, 1994, p. 33), visto que, apesar da luta da poetisa em manter o casamento, sem o real afeto entre ambos, tudo se torna superficial e efêmero, assim como os sentimentos do Príncipe para com ela.

O Diário termina com uma visão melancólica da autora sobre seus anos narrados, conforme excerto a seguir:

4 Kami - tio de Michitsuna e seu chefe no posto burocrático que havia sido atribuído a ele, quando fez 15 anos. Anos depois Kami tornar-se-ia noivo da filha de Kaneie, que seria adotada pela autora do diário. 
O clima foi ficando razoavelmente bom pelo resto do ano, com apenas alguns poucos acúmulos de neve. Nós estávamos ocupados preparando o garoto para o dia de Ano Novo e para o Festival dos Cavalos Brancos. Enquanto eu supervisionava a preparação dos presentes que ele levaria consigo, eu comecei a pensar na rapidez com que os anos se passaram e cada um com o mesmo desejo não realizado. A velha e inexaurível tristeza voltou, e eu, distraidamente, me percebi indo pelos ritos dos meus ancestrais. Mais tarde, na noite da véspera de Ano Novo, houve uma batida lá fora. (MICHITSUNA NO HAHA, 1994, trad. nossa, p. 167)

Sem expectativa de mudança, o Diário da Efemeridade, mais do que um texto de lamentações sobre um casamento mal sucedido, revela os sentimentos da mulher que se vê sempre à espera da resposta do homem, e a resiliência desta a fim de se manter viva em prol de seu filho.

O diário da dama da corte, diferentemente do diário de Ki no Tsurayuki, aborda como observamos anteriormente reflexões mais profundas sobre a vida e o futuro, não se tratando apenas de um "simples" diário. De acordo com Miner (1968), a obra seria um dos maiores exemplos de diário artístico mesclando a sua prosa ao lirismo poético, ao ponderar sobre o fluxo do tempo, questionar os valores estabelecidos, sobretudo relativos ao matrimônio, e revolucionar a prosa ao confrontar a realidade do cotidiano de dama da corte à idealização da vida amorosa. Nesse sentido, é possível ver um nível de elaboração das imagens e episódios do diário com grande peso da particularização da situação da mulher japonesa naquele contexto vivido pela autora, embora ela se utilize de um gênero comumente empregado em sua época para o registro de acontecimentos banais. Além disso, a autora torna sua obra ainda mais voltada para a esfera particular (no caso, a literatura clássica japonesa) ao compor seu requintado ponto de vista na escrita e redefinir os parâmetros contemporâneos à sua obra.

\section{CONSIDERAÇÕES FINAIS}

As duas obras, embora contemporâneas uma da outra, e mescladas de lirismos, devido aos inúmeros poemas que encontramos em ambas, refletem de forma clara a formação e o gênero de seus autores. Aqui não nos cabe dizer qual obra é a mais verossímil, mas o que nos interessa é depreender se há diferenças na escrita e quais as implicâncias dessas diferenças no sentido das obras. As particularidades substancialmente significativas nos dois diários que apresentamos neste artigo nos levam a refletir sobre o caráter de escrita universal, bastante questionado pelos estudos literários contemporâneos, em suas mais diversas linhas críticas.

A escolha de cada voz narrativa dá o tom das diferenças entre as obras e, mais que isso, particularizam-nas dentro de uma opção em comum. Não à toa, o autor do Diário de Tosa se utiliza da voz narrativa feminina para exprimir seus sentimentos de tristeza para falar do falecimento da filha. A autora do Diário da Efemeridade se afasta de seu "eu" para tentar olhar com clareza para suas memórias. 
No Diário da Efemeridade, notamos um modelo claramente poético e feminino, em meio a um espaço pessoal para exprimir dor e saudades do marido, ao descrever as situações vividas ao lado do Príncipe, não se importando tanto com as entradas de data ou tempo. O passado se mistura com reminiscências do presente, ao contrário do que acontece no primeiro diário de autoria masculina, em que apesar do tom lírico encontrado nos poemas, lembra - nos um relatório oficial de viagens, tamanhas as longas descrições dos cerimoniais e datas.

Enquanto o autor do Diário de Tosa busca descrever com detalhes o dia a dia da longa viagem de retorno a capital, recitando poemas que só a "voz narrativa feminina" conseguiria depreender e descrever, no Diário da Efemeridade, a autoria feminina observa questões mais intensamente sobre a vivência da mulher de Heian, não apenas como uma mera descrição dos fatos, mas reflexões densas sobre a vida das damas que viveram naquele momento. Assim, embora a obra de Ki no Tsurayuki tenha como base uma narradora feminina, é apenas no Diário da Efemeridade que traços de um estilo claramente feminino podem ser percebidos.

As duas obras fazem parte do cânone literário japonês, mas enquanto uma utiliza-se de técnicas narrativas claramente modernas até na atualidade, a outra reflete a intimidade das memórias da mulher de seu tempo, o que torna o texto mais próximo do leitor atual, a nosso ver. Assim, se o leitor busca entender as técnicas da narrativa do século $\mathrm{X}$ e a vida dos governantes da época, a leitura do Diário de Tosa torna-se uma obra de grande referência. No entanto, se há no leitor o desejo por conhecer "os bastidores" de um tempo histórico e a vida das mulheres que viveram naquela época, apenas no Diário da Efemeridade teremos uma visão mais próxima da realidade. Observando as duas obras, ao final, temos expressões claras não apenas do tempo narrado, mas das memórias de um povo inscrito e registrado por meio do gênero memorialístico.

\section{REFERENCIAS:}

BUNDY, Roselee. Japan's First Woman Diarist and the Beginnings of Prose Writings by Women in Japan. Women's Studies, vol. 19, pp. 79 - 97, 1991, Disponível em: https://doi.org/10.1 080/00497878.1991.9978855> Acesso em: 19 de out de 2017.

FRIEDMAN, Norman. O ponto de vista na ficção - o desenvolvimento de um conceito crítico. Trad. Fábio Fonseca de Melo. Revista USP, n.53, 2002, p. 166-182.

KI NO TSURAYUKI. Tosa Nikki. In: MORI, Michiyo et al. (orgs). Koten Nihon Bungaku Zenshū (Literatura Clássica Japonesa - Obras Completas) - Ōchō Nikki Shū (Diários Completos da Dinastia Heian). Vol. 08. Tóquio: Kasamashoin, 1960. pp. $04-28$.

KI NO TSURAYUKI. Diário de Tosa (Tosa Nikki). Tradução Neide Hissae Nagae 2014. (Tradução Inédita)

KLINGER, Diana Irene. ESCRITAS DE SI, ESCRITAS DO OUTRO: $o$ retorno do autor e a virada etnográfica, Rio de Janeiro: 7Letras, 2007. 
MAGALHÃES, Isabel Allegro. Diferenças Sexuais na Escrita: ao contrário de Diotima. In: CIEG (Centro Universitário de Estudos Germanísticos). Actas do Colóquio "Escrita de Mulheres". Coimbra: Universidade de Coimbra, 2004, n 9, pp. 09 - 23.

MATHIAS, Marcelo Duarte. Autobiografias e Diários. Revista Colóquio/ Letras, nº 143/144, jan.1997, pp. 41 - 62. Disponível em: < http://coloquio.gulbenkian.pt/bib/sirius.exe/getrec? $\mathrm{mfn}=7522 \& \_$template $=$singleRecord $>$Acesso em: 09 de novembro de 2017

MICHITSUNA NO HAHA. Kagerō Nikki (O Diário da Efemeridade). In: MORI, Michiyo et al. (orgs). Koten Nihon Bungaku Zenshū (Literatura Clássica Japonesa - Obras Completas) - Ōchō Nikki Shū (Diários Completos da Dinastia Heian). Vol. 08. Tóquio: Kasama Shoin, 1960. pp. $29-150$.

MICHITSUNA NO HAHA. The Gossamer Years. [Kagerō Nikki]. Trad. Edward Seidensticker. Tokyo: Charles E. Tuttle, 1994.

MINER, Earl. The Traditions and Forms of the Japanese Poetic Diary. Pacific Coast Philology. Vol. 3, Abril- 1968. Penn State University; pp. 38 - 48.

NAGAE, Neide Hissae. O surgimento do diário como obra literária na literatura clássica japonesa. Estudos Japoneses, n.22, 2002, pp. 91-102.

NAGAE, Neide Hissae. A Voz narrativa e os poemas nos diários literários japoneses: Tosa Nikki e Izumi Shikibu Nikki. Estudos Japoneses, n.27, 2007, pp. 147-162.

SEIDENSTICKER, Edward. Introduction. In: MICHITSUNA NO HAHA. The Gossamer Years. [Kagerō Nikki]. Trad. Edward Seidensticker. Tokyo: Charles E. Tuttle, 1994, pp. 07 - 29.

SUZUKI, Tae. A sociedade da época Heian. Estudos Japoneses, nº 12, 1992, pp. 133 - 142. 